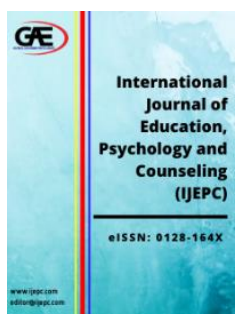

\author{
INTERNATIONAL JOURNAL OF \\ EDUCATION, PSYCHOLOGY \\ AND COUNSELLING \\ (IJEPC) \\ www.ijepc.com
}

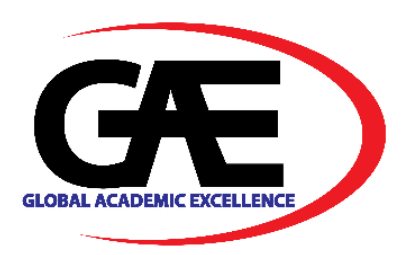

\title{
DEVELOPMENT A CONTENT MODEL OF TEACHING ARABIC IN MASSIVE OPEN ONLINE COURSES (MOOC) AT HIGHER EDUCATION INSTITUTIONS
}

\author{
Sofia Noraina, $\mathrm{I}^{1^{*}}$, Ghazali, $\mathrm{Z}^{2}$, Irwan Mahazir, I ${ }^{3}$, Norfaezah M.H ${ }^{4}$ \\ $1 \quad$ Faculty Education, Kolej Universiti Islam Antarabangsa Selangor, Malaysia \\ Email: sofiaaina677@gmail.com \\ 2 Faculty of Islamic Civilisation Studies, Kolej Universiti Islam Antarabangsa Selangor, Malaysia \\ Email: ghazali@kuis.edu.my \\ 3 Centre of Instructional Technology \& Multimedia, Universiti Sains Malaysia, Malaysia \\ Email: irwanmahazir@usm.my \\ $4 \quad$ Pusat Pengajian Teras, Kolej Universiti Islam Antarabangsa Selangor, Malaysia \\ Email: norfaezah@kuis.edu.my \\ Corresponding Author
}

\section{Article Info:}

Article history:

Received date: 26.09 .2021

Revised date: 06.10.2021

Accepted date: 20.11 .2021

Published date: 01.12.2021

\section{To cite this document:}

Sofia, N. I., Ghazali, I., Irwan, M. I., \& Norfaezah, M. H.. (2021). Keperluan Modul Pembelajaran Sosial Dan Emosional: Satu Analisis Literatur Sistematik. International Journal of Education, Psychology and Counseling, 6 (44), 68-80.

\section{DOI: $10.35631 /$ IJEPC.644006}

This work is licensed under CC BY 4.0

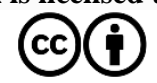

\begin{abstract}
:
Online learning systems are viewed as a potentially significant platform for learning and teaching (T\&L) process during the Covid-19 pandemic that has spread worldwide since December 2019. Massive Open Online Courses (MOOC) is one of popular online learning platforms used around the world and has gain attention among lecturers nowadays in higher education institutions (HEIs). Due to its features, many institutions as well as in Malaysia started to develop MOOC as learning and teaching platform especially for Arabic language. However, problems that are often faced by Arabic language lecturers are less confident in producing aspects of multimedia teaching content. Hence, the purpose of this paper is to develop the content model of teaching Arabic in MOOC using Interpretive Structural Modelling (ISM) technique. A total of 14 elements identified by the agreement of 7 experts for the content model of Arabic MOOC which was generated through ISM software. Based on the findings, there are two most important elements; the element of determine topics, objectives, and learning outcomes for students to understand better the purpose of learning and element of ensure course materials use the appropriate type of writing for students' understanding while this model ends with the element of providing comment space to encouraged interaction among learners and lecturers. It is hoped that the study could be a reference and suggestion to Arabic lecturers in using the MOOC as a teaching
\end{abstract}




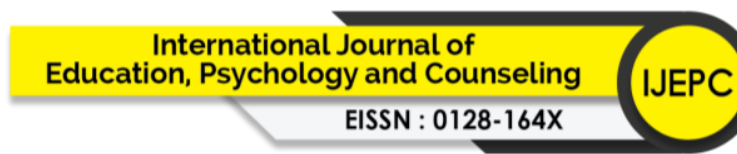

Volume 6 Issue 44 (December2021) PP. 68-80 DOI 10.35631/IJEPC.644006

platform while increase the effectiveness of MOOC implementation in Malaysian higher education institutions.

\section{Keywords:}

MOOC; Content Model; Teaching Arabic Language; Interpretive Structural Modelling (ISM); Higher Education Institutions

\section{Introduction}

In the last few years, in the area of online teaching and learning (T\&L) a new technologically innovative methodological approach has come into play with significant acceptance in different areas of study, namely, MOOC (Massive Online Open Courses). MOOC are viewed as a potentially significant platform for $T \& L$ process and being popularly used all over the world especially in higher education institutions (HEIs) (Hafiza et al., 2019) since all countries had to close education sector due to the covid-19 pandemic which has been spreading around the world since December 2019. Massive and open indicate that it is offerings unlimited courses with the option of free and open registration. Online Course also gives the impression that teaching and learning is delivered online and there is enable to transfer credit for certification (Farah Nurshahira \& Md Yusoff, 2017).

In Malaysia, implementation and the use of the MOOC is still at the initial stage and MOOC is considered a new initiative by the government to boost the technological level of public and private universities (Norazah, Helmi, \& Mohamad Amin, 2016). The Malaysian government is very supportive in using MOOC and sees it as a platform to integrate learning technology, lifelong learning and concurrently lead the way towards a new direction in teaching methodologies for undergraduate programmes (Ministry of Education of Malaysia, 2012). The MOOC Initiative was launched at the public university level in 2013 and it was initially apply to core courses at universities such as the Islamic Civilization and the Asian Civilization (TITAS), Ethnic Relations, Entrepreneurship Intentions and ICT Competencies. As of December 2014, 20 public universities have used MOOC as a learning platform (Rozilawati et al., 2018). Since covid-19 pandemic, MOOC in MARA University of Technology (UiTM) now reaches more than 170,000 students actively offering 538 courses in various fields for lifelong learning, full-time and part-time and short-term courses. UiTM Institute of Continuing Education and Professional Studies (iCEPS) Chief Executive Officer, Prof Dr Azizul Halim Yahya said, MOOC is a facilitator for various learning methods implemented at UiTM (Berita Harian, 2020).

In addition, from a methodological point of view, MOOC appear to have great potential for improve language skills among lecturers and students (Aljaraideh, 2019) and self-directed English language learning as: (a) there is a possibility for the use of audiovisual materials; (b) the use of the Internet allows oral and written interaction between language learners at the same proficiency levels; (c) they favour collaborative learning; (d) they allow language learners to proceed at their own pace (e) they promote learner autonomy; (f) they encourage the sharing of Internet-based resources; (g) they favour empathy and cooperation between students sharing the same interests (Chacón-Beltrán, 2017). 


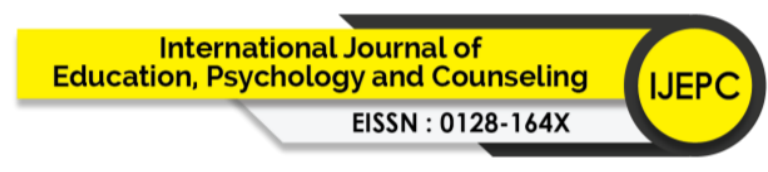

Volume 6 Issue 44 (December2021) PP. 68-80 DOI 10.35631/IJEPC.644006

Therefore, some universities in Malaysia started to design and develop MOOC for teaching and learning process (T\&L) Arabic language in MOOC platform because of teaching and learning of Arabic language in MOOC is still not widespread like another languages. The existence of learning language in MOOC was detected since 2013 (Gilliland et al., 2018) but for learning of English language only (Ghazali \& Siti Rosilawati, 2018). Universiti Sains Islam Malaysia (USIM) is one of universities which offers courses through the MOOC platform using Arabic medium since 2015. According to the June 2016 data, a total of 968 students from eight countries have registered for the first three courses at the USIM MOOC.

However, there are problems that often faced by Arabic language lecturers in using MOOC platform which are less confident in producing aspects of multimedia teaching content (Rozilawati et al., 2018) and the material provided by the lecturers is cheesed off and uninterested (Norfarahi et al., 2020). The results of a study conducted by Chengjie., (2015) statistics show that only 5 to $15 \%$ of students are able to complete their studies at MOOC (Norliza \& Mohamad Sahari, 2016). The main reason of this situation is due to the lack of interaction activities between students and lecturers (Almahdi \& Sulfeeza, 2017). It shows that some lecturers are not clear enough in using and design MOOC especially for content aspect. Therefore, this study aimed to develop a content model of teaching Arabic in MOOC at higher learning institution. Based on the research objectives, the research questions are as follows:

a) What are the content elements of teaching Arabic in MOOC at higher learning institution as suggested by consensus of experts?

b) What is the shape of the content model of teaching Arabic in MOOC at higher learning institution according to consensus of experts?

\section{Literature Review}

In their study, Chacón-Beltrán (2017) focused on the role of MOOC in the learning of English languages. The findings of the study claimed, MOOCs are a teaching and learning methodology that can be adapted to all educational levels, fields of study, ages and geographical areas of the world. Other than that, Gilliland et al., (2018) conducted a study entitled second Language Writing In A MOOC: Affordances And Missed Opportunities can conclude that factors essential to course design were the language level and appropriateness of texts and activities, the structure of the peer review sessions and discussion boards, and the production of instructional videos. In a study by Perifanou \& Economides, (2014) focus on the basic characteristics of a successful online language learning course and its transition to a massive open online language course (MOOLC) globally. In this paper, the authors tried to show that there is a growing interest for MOOLCs and proposed an evaluation framework that could help instructional designers to create successful massive open interactive language learning environments. Additionally, a study by Nuraihan et al., (2018) highlights that in MOOC, each approach has its strength, and each one contributes to the development of students' critical thinking skills. The adoption of these activities can make the class more lively and will give students the opportunity to use the language in a more meaningful way.

Others investigated characteristics related to Arabic language, Hamdani \& Taghipour Birgani (2019) examined the three effectiveness aspects on comprehension and translation, grammar, and the total grade of the Arabic language in high schools of Ahvaz city. The result of the study showed that this method with significant level of $p<0.05$ did not have effect on the improvement of comprehension and translation skill of students but had significant positive Copyright (C) GLOBAL ACADEMIC EXCELLENCE (M) SDN BHD - All rights reserved 


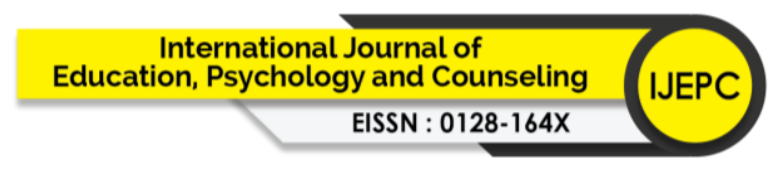

Volume 6 Issue 44 (December2021) PP. 68-80

DOI 10.35631/IJEPC.644006

influence on grammar skill of students and finally, it had considering effect on the total grade of Arabic of female students of Ahvaz city. Other previous researcher, Salmah Jan (2019) had been focusing on apply MOOC as a flexible knowledge transfer method in reviewing the Malay manuscript by describing the content, activities and assessment among related students. The data for this study is obtained from the library and the questionnaire survey among the undergraduate students of BBK 4210 Karya Agung Melayu. The findings of this study are expected to prove that MOOC applications are one of the most effective and flexible learning mediums for promoting Malay manuscripts. In view of this, it shows that MOOC very effective in teaching and learning language but very little research has been done to develop a model of MOOC especially for Arabic language as guider in teaching Arabic language for lecturers. Therefore, there is a need for a review of relevant MOOC literature to gain a better understanding of the phenomenon.

\section{Methodology}

In developing a curriculum content model of teaching Arabic in MOOC, using ISM software is one basic idea to apply practical experience and expert knowledge for breaking down a complex system into several subsystems and at the same time building a hierarchical structural model. ISM was first proposed by J. N. Warfield. Warfield (1982) described ISM as "a computer assisted learning process that enables an individual or a group user to develop a structure or map showing interrelations among previously determined elements according to a selected contextual relationship'. It could also be viewed as a management decision-making tool that interconnects ideas of individuals or groups to facilitate thorough understanding of a complex situation through a map of relationships between many elements involved in the complex decision situation (Charan et al, 2008). ISM is interpretive because it involves judgment whether there are relationships among elements and if so how they should be connected. The method is structural because an overall structure could be generated using the relationships among the elements. Finally, it is a modelling technique because the overall structure and the relationships among the elements could be illustrated in a graphical model.

In the context of this study, ISM is used to help the panel of experts achieve consensus in concluding the relationship between the elements of content model of teaching Arabic in MOOC presented in designing a model structure. A total of 7 experts in the subject matters (SME) were brought together in online workshop to develop the model. Selection of the panel was made through referrals by other experts who had wide experience related to the context of the study. Findings from the selected panel included experts in teaching Arabic, information and communications technology and assessment. The following are the main steps in the ISM procedure.

\section{Step 1}

Identifying elements which are relevant to the problem or issues. In this study, the researcher identified the elements based on problems statement, literature review and the needs analysis. The authors employed a modified Nominal Group Technique (NGT) to identify the elements.

\section{Step 2}

Determine the contextual relationship and relation phrase with respect to how the learning activities (elements) should be connected with each other. 


\section{Step 3}

Develop a structural self-interaction matrix (SSIM) of the content elements which shows the connection among elements. This was conducted using the aid of ISM software. Pairs of elements would be displayed by the software to allow the experts to decide through voting on the relationship before the next pair of elements was displayed. This process was repeated until all the elements being paired for relationship.

\section{Step 4}

Generate the ISM model. This was done by the software after the pairings of elements was successfully conducted. The software derives the model based on the concept of pair wise comparison as and transitive logic. Transitive Logic states that for any 3 elements (A, B, C) with a given relation when:

- A has the relation to $\mathrm{B}$, (written $\mathrm{A} \rightarrow \mathrm{B}$ ),

- And $\mathrm{B}$ has the relation to $\mathrm{C}$, (written $\mathrm{B} \rightarrow \mathrm{C}$ ), $\bullet$ Then $\mathrm{A}$ has the relation to $\mathrm{C}$, (written $\mathrm{A} \rightarrow \mathrm{C}$ or $\mathrm{A} \rightarrow \mathrm{B} \rightarrow \mathrm{C}$ ).

\section{Step 5}

The model was then being reviewed by the experts to check for conceptual inconsistency and making the necessary modifications.

\section{Step 6}

The final model was then presented after the necessary modifications were made.

\section{Result}

\section{Findings From Step I}

Table 1 shows the experts collective views on the elements which should be included in the development of the content model for teaching Arabic in MOOC via Nominal Group Technique. This is based on the first research question which is from expert consensus, what the necessary elements of content model of teaching Arabic in MOOC. In the beginning of NGT session, fourteen original elements were presented to the experts and analysis of the discussions to be discarded and revised in terms of sentence structure to shortlist the final elements from expert consensus. The following are the final elements for the content model of teaching Arabic in MOOC:

Table 1: Experts' Agreement on The Elements to Be Included in The Content Model Of Teaching Arabic in MOOC

\begin{tabular}{|c|c|c|c|c|c|}
\hline No. & Elements & $\begin{array}{l}\text { Total } \\
\text { Score }\end{array}$ & $\begin{array}{c}\text { Percentage } \\
\%\end{array}$ & $\begin{array}{c}\text { Expert } \\
\text { Consensus }\end{array}$ & Ranking \\
\hline 1. & $\begin{array}{l}\text { Provides } \\
\text { the latest } \\
\text { reference } \\
\text { materials } \\
\text { and } \\
\text { additional } \\
\text { resources } \\
\text { (ppt, pdf, }\end{array}$ & 23 & 92 & Accept & 2 \\
\hline
\end{tabular}


doc, html)

for

teaching

Arabic in

MOOC.

2. Determine

topics,

objectives,

and

learning

outcomes

for students

to

understand

better the

purpose of

learning.

3. Provides

quality and

suitable

teaching

materials

(video,

text, audio,

discussion

boards and

pictures)

for Arabic

language

teaching.

4. Ensure

23

96

Accept

1

24

96

Accept

1

course

materials

use

appropriate

language

levels for

students'

understandi

ng.

5. Ensure

22

88

Accept

3

course

materials

use the

appropriate

type of

writing for 
International Journal of

students'

understandi

ng.

6. Provide

19

76

Accept

subtitles in

each video

for students

to

understand

easily.

7. Ensure the

Accept

1

teaching

video is

short, not

too long

and attracts

students.

8. Provide

22

88

Accept

3

comment

space to

encouraged

interaction

among

learners

and

lecturers.

9. Ensure the

24

96

Accept

1

video and

image

introductio

$\mathrm{n}$ of the

course is

interesting.

10. Determine

21

84

Accept

4

an

attractive

montage

display to

welcome

users in the

course.

11. Ensure

23

92

Accept

2

content is

organized

and avoid

from any

spelling 
errors

occur.

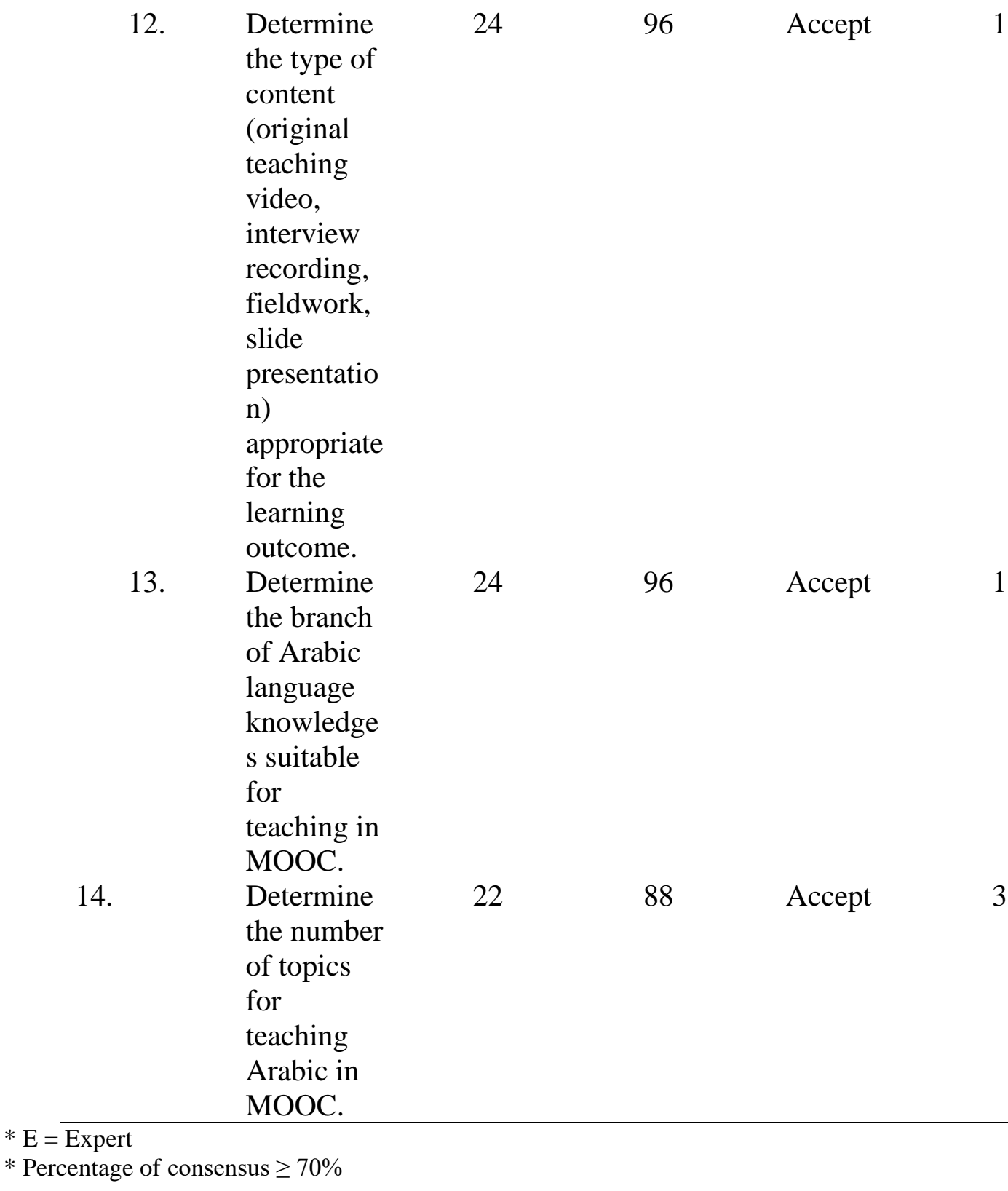

Based on the Table 1 showed that all the elements are accepted to be in the content model of teaching Arabic in MOOC based on voting that has been conducted and the percentage of the elements are at an appropriate level for use. These findings are in line with the arguments expressed in the study by Deslandes et al., (2010) and Dobbie et al., (2004) that the condition for the acceptance of an element is that the value of the voting percentage must exceed 70 percent. Therefore, the Nominal Group Technique session reveals that the experts consensually agreed on all the elements as listed in the table for the construction of the structural content model of teaching Arabic in MOOC at higher education institutions. 


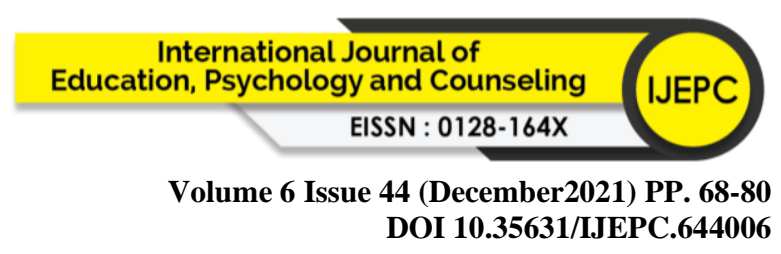

\section{Findings From Step 2}

Analysis of results in the second step of the ISM namely identifying the type of ISM to be constructed had determined the connection phrase and contextual phrase to be structured in the ISM. The findings show that the phrase appropriate to the context of the study is as follows:

The association/relationship/connecting phrase: "Element...MUST be conducted BEFORE element..."

The contextual phrase: "In implementing the teaching of Arabic at MOOC, element..."

The phrase concerned is selected as the procedure phrase of ISM because the researcher wants to identify the relationship from the perspective of importance of the content elements constructed from the context of development a content model of teaching Arabic in MOOC at higher learning institution. The connecting phrase was also agreed upon by the experts.

\section{Findings From Step 3 \& Step 4}

The findings from the third and fourth steps are the most critical namely the development of elements of content for teaching Arabic in MOOC that have been agreed upon and have received consensus from the panel of experts on the relationships of the elements using pair wise technique with the aid of the ISM software.

These steps are the process whereby software namely ISM carries out mathematical calculation using technology. Based on the questions according to the paired elements suggested by the ISM software administered by the facilitator, the expert panel had achieved consensus according to majority vote for each element presented. In these steps, the facilitator plays a role to explain the situation or in interpreting the meaning of the problem put forward by ISM. The findings of this stage form the findings leading to decision on consensus of experts with the final presentation of digraph produced as computer output. The digraph that shapes the model is given in Figure 1.

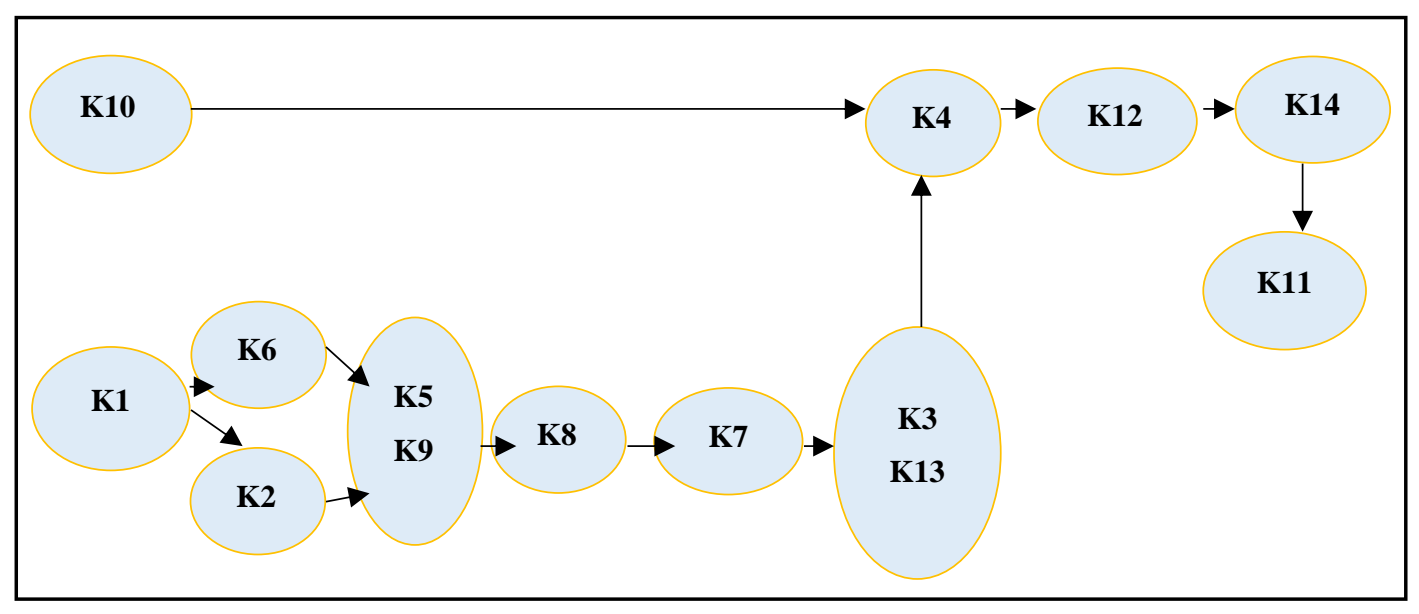

Figure 1: Content Model Of Teaching Arabic In MOOC 
Volume 6 Issue 44 (December2021) PP. 68-80

DOI 10.35631/IJEPC.644006

Table 2: Shows Complete Sentences Of Each Symbols in The Figure 1

\begin{tabular}{|c|c|}
\hline Symbols & Content Elements \\
\hline K1 & $\begin{array}{l}\text { Determine topics, objectives, and learning outcomes for students to } \\
\text { understand better the purpose of learning. }\end{array}$ \\
\hline $\mathrm{K} 2$ & $\begin{array}{l}\text { Provides quality and suitable teaching materials (video, text, audio, } \\
\text { discussion boards and pictures) for Arabic language teaching. }\end{array}$ \\
\hline $\mathrm{K} 3$ & Ensure the teaching video is short, not too long and attracts students. \\
\hline K4 & Ensure the video and image introduction of the course is interesting. \\
\hline K5 & $\begin{array}{l}\text { Determine the type of content (original teaching video, interview } \\
\text { recording, fieldwork, slide presentation) appropriate for the learning } \\
\text { outcome. }\end{array}$ \\
\hline K6 & $\begin{array}{l}\text { Determine the branch of Arabic language knowledges suitable for } \\
\text { teaching in MOOC. }\end{array}$ \\
\hline K7 & $\begin{array}{l}\text { Provides the latest reference materials and additional resources (ppt, } \\
\text { pdf, doc, html) for teaching Arabic in MOOC. }\end{array}$ \\
\hline K8 & $\begin{array}{l}\text { Ensure course materials use appropriate language levels for students' } \\
\text { understanding. }\end{array}$ \\
\hline K9 & Ensure content is organized and avoid from any spelling errors occur. \\
\hline K10 & $\begin{array}{l}\text { Ensure course materials use the appropriate type of writing for } \\
\text { students' understanding. }\end{array}$ \\
\hline K11 & $\begin{array}{l}\text { Provide comment space to encouraged interaction among learners } \\
\text { and lecturers }\end{array}$ \\
\hline K12 & Determine the number of topics for teaching Arabic in MOOC. \\
\hline K13 & $\begin{array}{l}\text { Determine an attractive montage display to welcome users in the } \\
\text { course. }\end{array}$ \\
\hline
\end{tabular}

K14 Provide subtitles in each video for students to understand easily.

\section{Findings from Step 5 \& Step 6}

The findings of the final stage namely discussion and amendment of structure showed that the panel of experts have achieved consensus to retain without amendment the module design produced. Before decision was made for retaining the constructed model, the facilitator explains and interprets the structure of relationship between the content elements developed. The panel of experts have confirmed the resulting model.

Based on figure 1, result showed that the model can be divided into three flows of implementation of contents. For the first flow showed that the element K10 (Ensure course materials use the appropriate type of writing for students' understanding) was in highest level and higher driving power other than elements K4, K12, K14 and K11.

Driving power is the power that drives other elements or activities in achieving goals and goals in itself (Muhammad Ridhuan et al., 2013). Dependence power on the other hand, it is a power that depends on other powers in achieving a goal and purpose. 


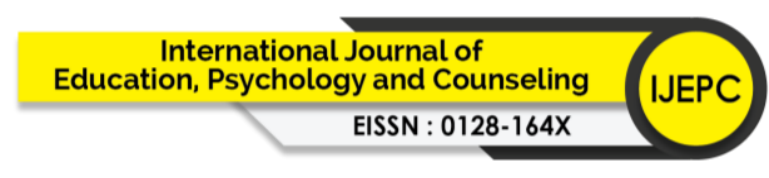

Volume 6 Issue 44 (December2021) PP. 68-80

DOI 10.35631/IJEPC.644006

While in second and third flows showed that the element K1 (Determine topics, objectives, and learning outcomes for students to understand better the purpose of learning) was in highest level and was higher driving power other than elements K6, K2, K5, K9, K8, K7, K3, K13, K4, K12, K14 and K11. Elements K11 (Provide comment space to encouraged interaction among learners and lecturers) is placed at the lowest position in the digraph. It showed that element K11 have highest dependence power.

\section{Discussion}

To answer the first research question, elements of the content model of teaching Arabic in MOOC at higher learning institution have resulted from the views and discussions among experts through the NGT namely the fourth stage in the ISM procedure. The findings of analysis listed 14 elements of the content teaching Arabic in MOOC that needed to be inserted into the content model as given in Table 1.

Based on the findings for research question 1, analysis of expert consensus showed the model design as in Figure 1. The findings showed that the model can be divided into three flows of implementation of contents model of teaching Arabic in MOOC. In first flow shows element $\mathrm{K} 10$ ensure course materials use the appropriate type of writing for students' understanding must be carried out before element K4, K12, K14 and K11. This coincides with the study of Md Yusoff et al., (2017) had developed a MOOC course - "Jom Belajar Adobe Photoshop". According to him based on the design and content aspects of the MOOC that have been developed, "The selection of fonts in the MOOC is appropriate and easy to read", record the highest mean value. Therefore, it cannot be denied that the type of writing plays important roles in MOOC.

Referring back to the model in Figure 1, in second and third flows showed that element 1 namely determine topics, objectives, and learning outcomes for students to understand better the purpose of learning is positioned highest in this content model. This element is the most preliminary elements which need to be conducted before other elements as other elements depend on them. This is in line with the study by Ahmad Nasir \& Noralina (2018) which the main strategy of implementing collaborative learning in MOOC and open learning platform is identifying learning outcomes for each task or project that will be implemented by students. This finding is closely related to study by Salmah Jan (2019) that in developing content in MOOC should be start with explanation main topics and learning outcomes of the courses. Meanwhile, the content element at the lowest level in the three flows of content model is provide comment space to encouraged interaction among learners and lecturers. This element is the last elements which need to be conducted after elements $\mathrm{K} 14, \mathrm{~K} 12, \mathrm{~K} 4, \mathrm{~K} 13, \mathrm{~K} 3, \mathrm{~K} 7$, $\mathrm{K} 8, \mathrm{~K} 9, \mathrm{~K} 5, \mathrm{~K} 2, \mathrm{~K} 10$ and K1. This is in line with the study (Md Yusoff et al., 2017; Subramaniam et al., 2018) agreed that comment space in MOOC such as chatboxes, bulletins and forums allows students to ask questions about topics or topics that are poorly understood. Instructors can provide additional guidance and explanations to help graduates understand the topic or topic being studied. At the same time, it can encourage students doing discussions with other students who follow the course. Therefore, provide comment should be given emphasis after determine the number of topics for teaching Arabic in MOOC and provide subtitles in each video for students to understand easily. 


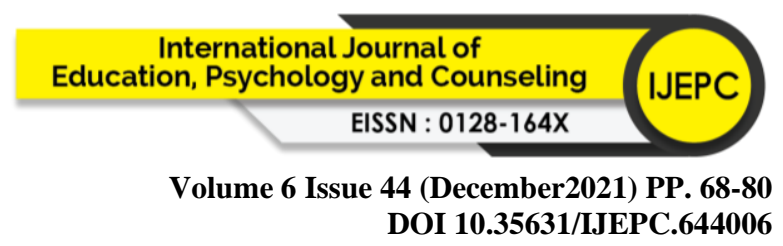

\section{Conclusion}

In relation to the first research question, the data analysed in the previous section allows us to conclude that 14 elements should be included in the content model of teaching Arabic in MOOC. Its showed that Nominal Group Technique (NGT) helped to unite various opinions of individuals to reach a consensus in prioritizing issues and suitable technique to be combined together in the ISM process. Consideration of these elements will ensure that the MOOC is designed and delivered effectively to ensure meaningful learning occurs and result in learning satisfaction among MOOC learners, there by achieving success with MOOC systems.

In relation to the second research question, the model was divided into three flows. Development the content model of teaching Arabic language in MOOC using consensus of the experts through the Interpretive Structural Modelling (ISM) process has been able to assist and be able to resolve in developing a structure, framework and model. It is hoped that this study could be a reference and suggestion to Arabic lecturers and other language lecturers in using MOOC as a teaching platform.

As MOOC of Arabic language is still a new project in the Malaysian higher education context, this study only highlighted the development content of teaching Arabic language in MOOC. We hope future studies may explore and design activities and evaluation which are significant parts in design MOOC. In addition, future works may also look at identifying the needs of lecturers in using and design MOOC to ensure that they are ready and fully-armed with the pedagogical approaches needed in planning and implementing MOOC to result in satisfaction and meaningful learning experiences for MOOC learners.

\section{References}

Ahmad Nasir, M. Y., \& Noralina, A. (2018). Penerapan Model Kolaboratif E-Learning dalam Kursus TITAS MOOC dan Aplikasinya dalam Platform OpenLearning Versi 2. Prosiding Persidangan Antarabangsa Sains Sosial Dan Kemanusiaan, April, 516-521. Aljaraideh, Y. (2019). Massive Open Online Learning (MOOC) Benefits and Challenges: A Case study in Jordanian context. International Journal of Instruction, 12(4), 65-78.

Almahdi, M. Ejreaw \& Sulfeeza Mohd Drus. (2017). The Challenges of Massive Open Online Courses (MOOCs), Proceedings of the 6th International Conference on Computing \& Informatics: 473-479.

Anin. 2020. COVID-19 Jadikan Pembelajaran Maya Satu Keperluan. Berita Harian, 22 April. Chacón-Beltrán, R. (2017). The Role of MOOCs in The Learning of Languages: Lessons from A Beginners' English Course. Porta Linguarum, 2017(28), 23-35.

Charan, P., Shankar, R., \& Baisya, R.K. (2008). Analysis of Interactions among Variables of Supply Chain Performance Measurement System Implementation. Business Process Management Journal, 14(4), 512-529.

Chengjie, Y. (2015). Challenges and Changes of MOOC to Traditional Classroom Teaching Mode. Canadian Social Science, 11(1), 135-139.

Farah Nurshahira, Z., \& Md Yusoff, D. (2017). Transformasi Pendidikan : Isu Dan Cabaran Pendidikan Abad Ke-21 Melalui Aplikasi Massive Open Online Courses (MOOC) di Malaysia. In Simposium Pendidikan diPeribadikan: Perspektif Risalah An-Nur (SPRiN 2017).

Ghazali, Z., \& Siti Rosilawati, R. (2018). Moocs Untuk Pembelajaran Bahasa: Satu Tinjauan Literatur Sistematik. September, 893-902. 


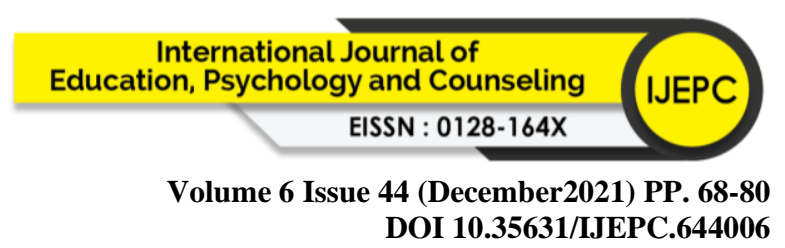

Gilliland, B., Oyama, A., \& Stacey, P. (2018). Second Language Writing in a MOOC: Affordances And Missed Opportunities. 22(1), 1-25.

Hafiza, H., Ahmad Rizal, M. Y., Hafiza, S., Noraini, I., Anis, J., \& Hafidzan, Y. (2019). The Platform of MOOC (Massive Open Online Course) on Open Learning: Issues And Challenges. International Journal of Modern Education, 1-9.

Hamdani, M. (2019). Examining The Effectiveness of The Educational System of Massive Open Online Courses ( MOOCs ) on Teaching Arabic in Girl's High Schools of Ahvaz City. IRAQI Academic Scientific Journal, 1(40), 721-736.

Md Yusoff, D., Farah Nurshahira, Z., Mohd Jasmy, A. R., \& Fariza, K. (2017). Kesediaan Pelajar Siswazah Menggunakan MOOC Dalam Pengajaran Dan Pembelajaran. 636651.

Muhammad Ridhuan Tony Lim, A., Saedah, S., Asra, S. \& Zaharah, H. (2013). Interpretive Structural Modeling Of M-learning Curriculum Implementation Model Of English Language Communication Skills For Undergraduates. The Online Journal of Distance Education and e-Learning, 1(2), 13-26.

Norfarahi, Z., Mohd Isa, H., \& Bashah, N. H. (2020). Challenges to Teaching and Learning Using MOOC. Scientific Research Publishing, 197-205.

Norliza, G., \& Mohamad Sahari, N. (2016). The Perception of University Lecturers of Teaching and Learning in Massive Open Online Courses ( MOOCS ). Journal of Personalized Learning, 2(1), 52-57.

Nuraihan, Mat Daud, Afiza, Mohamad Ali, Nor Shidrah, Mat Daud, Jowati, Juhary \& Raihanah, M.M. (2018). A MOOC for Literature Integrated Language Classroom: Pedagogical Suggestions for The Development of Higher Order Thinking Skills(HOTS). Arab World English Journal (AWEJ), 2(4), 1-45.

Rozilawati, S., Yusdi, I., \& Roseline, A. K. (2018). Introduction to Massive Open Online Course ( MOOC ): The Issues and Challenges using MOOC As A Teaching and learning Method in Malaysian Polytechnic. RMP Publications, January.

Salmah Jan, N. M. (2019). Pembelajaran Fleksibel Berasaskan Massive Open Online Course ( MOOC ) Suatu Transformasi dalam Pengajian Manuskrip Melayu. International Journal of the Malay World and Civilisation, 7(3), 63-73.

Subramaniam, T. S., Nor Amirah, S., Norhasyimah, H., Arihasnida, A., \& Siti Nur Kamariah, R. (2018). Pembangunan dan Pengujian Aktiviti Pembelajaran Berasaskan MOOC Untuk Kursus Diagnous Dan Senggaraan Audio Video. Politeknik \& Kolej Komuniti Journal of Social Sciences and Humanities, 3(3), 11-25.

Warfield, J.N. (1982). Interpretive Structural Modelling. In Olsen, S.A (Eds.), Group Planning and Problem Solving Methods in Engineering Management. New York, USA: John Wiley \& Son, Inc. 